\title{
Effect of different wavelengths of light on laccase, cellobiose dehydrogenase, and proteases produced by Cerrena unicolor, Pycnoporus sanguineus and Phlebia lindtneri
}

\author{
Grzegorz Janusz ${ }^{\bowtie}$, Justyna Sulej, Magdalena Jaszek and Monika Osińska-Jaroszuk \\ Department of Biochemistry, Maria Curie-Skłodowska University, Lublin, Poland
}

\begin{abstract}
Three species of white rot fungi: Cerrena unicolor, Phlebia lindtneri and Pycnoporus sanguineus were cultured in two different media under five different lighting conditions: dark, white, red, blue, and green light. Laccase, cellobiose dehydrogenase, and protease activities were examined in the samples. Blue light efficiently boosted laccase synthesis in $C$. unicolor and $P$. sanguineus, whereas the highest activities (20654 nkat/l) of $P$. lindtneri laccase were observed when this fungus was maintained in green light. On the contrary, the green light allowed obtaining the highest activities of cellobiose dehydrogenase of $C$. unicolor and $P$. lindtneri, while CDH of $P$. sanguineus seems to be dependent on white light. It is clearly visible that differences in protease activities are noticeable not only between the lights variants but also among the media used. However, high proteases activities are correlated with light variants inducing laccase in Lindeberg and Holm medium. Contrary to the cellulosebased medium, where they are weak in light variants that lead to high CDH activities.
\end{abstract}

Key words: white rot fungi, submerged cultures, visible light wavelenghts

Received: 07 January, 2016; revised: 08 January, 2016; accepted: 11 January, 2016; available on-line: 17 February, 2016

\section{INTRODUCTION}

During millions years of evolution, light became a crucial factor for most living organisms in terms of both the beneficial and harmful effects; moreover, it is considered as a main limiting condition for successful competition and survival in nature (Tisch \& Schmoll, 2010). In the past decade, explosion of interest in fungal photosensory abilities was observed considering their responses and molecular basis. It is worth noting that these analyses are significantly accelerated by the advances in genome sequencing, which provide information about the gene content in numerous and phylogenetically diverse fungal species. In a natural habitat, the ability to sense light for fungi means recognizing and anticipating conditions unfavourable for vegetative growth. Moreover, light is often needed for appropriate timing of production and dissemination of conidia (Tisch \& Schmoll, 2010). In the light of research conducted over the world, it should be mentioned that light influences many other fungal physiological responses such as asexual conidiation, the circadian clock, secondary metabolism, pigmentation, and sexual development. Therefore, it is not surprising that fungi are capable of sensing light over a broad-spectrum range, from ultraviolet to far-red light. Hence, a variety of photoreceptors are conserved in fungi, some of which have been analysed in the past few years (Purschwitz et al., 2006).

Numerous publications have been produced indicating that the numbers of genes regulated by light vary between organisms. For Trichoderma atroviride, an estimated $2.8 \%$ of the genome is light-regulated. Microarray studies on Neurospora crassa suggest light regulation in $3-7 \%$ genes; in contrast, less than a quarter of a percent $(0.25 \%)$ of the Cryptococcus neoformans genome was regulated by light (Rosales-Saavedra et al., 2006; Dong et al., 2008; Chen et al., 2009a; Idnurm \& Heitman, 2010). It has been proved many times that light is engaged in regulation of fungal carotenoid metabolism, polysaccharide and carbohydrate metabolism, fatty acid metabolism, nucleotide and nucleoside metabolism, and in regulation of production of secondary metabolites. Consequently, enzyme and metabolite synthesis is influenced via transcription of genes initiated within minutes in order to cope with the harmful effects of light or to prepare for reproduction (Tisch \& Schmoll, 2010).

Interestingly, many enzymes engaged in wood decomposition by fungi are also regulated by cAMP levels. During evolution, fungi became the most effective degraders of ligninocellulosis: in favourable conditions, they decompose wood mainly by fast mycelium growth. They are capable of production of hyphae penetrating into the wood and diffusing a variety of enzymes and low molecular compounds called mediators (Smith \& Berry, 1974; Kirk, 1987). Extensive research efforts have been dedicated to characterize regulation of the expression of wood degrading enzymes in numerous fungal species. However, until now only lignin peroxidase has been proved to be induced by light in Phanerochate chrysosporium (Ramirez et al., 2010). Analysis of available genomes of white rot fungi (Phanerochaete chrysosporium, Coprinopsis cinerea, Lentinula edodes) showed existence of homologous sequences to white collar proteins which are widely found in moulds. Therefore, it should be examined how different light conditions (dark and light lengths) will influence enzyme production in different fungal species. In this paper, we present the results of studies of the influence of light on the activity of laccase, cellobiose dehydrogenase, and proteases in three different fungal

e-mail: gianusz@poczta.umcs.lublin.pl

Abbreviations: FCL, Fungal Culture Collection of Lublin; DCIP, 2,6-dichloroindophenol; CDH, cellobiose dehydrogenase; WWC, white collar complex 
species: Cerrena unicolor, Pycnoporus sanguineus and Phlebia lindtneri.

\section{MATERIAL AND METHODS}

Culture conditions. The white rot fungi: Cerrena unicolor strain FCL139, Phlebia lindtneri strain FCL22, and Pycnoporus sanguineus strain FCL199 were obtained from the culture collection of Regensburg University, the Agriculture Academy in Cracow, and the Agriculture University, Tokyo, Japan (FCTUA), respectively. The fungi were maintained on $2 \%(\mathrm{w} / \mathrm{v})$ malt agar slants. As an inoculum, pieces of fungal mycelia were grown in Lindenberg and Holm medium (Lindeberg \& Holm, 1952) in non-agitated conical flasks for 7 days at $28^{\circ} \mathrm{C}$.

Mycelial mats were subsequently collected, broken in a Waring blender (three times for $15 \mathrm{~s}$ at $10000 \times \mathrm{g}$ ), and homogenates were used as inocula in shaken microplates. After inoculation with $10 \%$ (v/v) mycelial suspension, the shaken cultures were run up to 13 days at $28^{\circ} \mathrm{C}$ in 24 -well microplates (each well with $2 \mathrm{ml}$ of Lindeberg and Holm medium or cellulose-based medium placed in an orbital rotary shaker at $120 \mathrm{rpm}$ ). The cellulose-based medium had the following composition (1l): $2 \mathrm{~g}$ Avicel, $10 \mathrm{~g}\left(\mathrm{NH}_{4}\right)_{2} \mathrm{HPO}_{4}, 1 \mathrm{~g} \mathrm{KH}_{2} \mathrm{PO}_{4}$, $0.3 \mathrm{~g} \mathrm{MgSO}_{4} \times 7 \mathrm{H}_{2} \mathrm{O}_{2}, 0.08 \mathrm{~g} \mathrm{CaCl}_{2}, 5 \mathrm{mg} \mathrm{ZnSO} \times 7 \mathrm{H}_{2} \mathrm{O}$, $1.5 \mathrm{mg} \mathrm{MnSO}_{4} \times 4 \mathrm{H}_{2} \mathrm{O}, 1.5 \mathrm{mg} \mathrm{CoCl}_{2} \mathrm{z} 6 \mathrm{H}_{2} \mathrm{O}, 5 \mathrm{mg}$ $\mathrm{FeSO}_{4} \times 7 \mathrm{H}_{2} \mathrm{O}, 100 \mathrm{mg}$ yeast extract, and $0.1 \mathrm{mg}$ thiamine. The $\mathrm{pH}$ was adjusted to 6.5 with $5 \mathrm{M} \mathrm{HCl}$ (Fang et al., 1999). Every strain and light variant was run in four replications. The samples $(40 \mu \mathrm{l})$ were collected every 24-hours.

All analysed strains were grown under five different conditions of lighting: dark, white, blue (325-495 nm), green $(450-590 \mathrm{~nm})$, and red $(600-700 \mathrm{~nm})$. As the dark variants microplates were completely covered with aluminium foil to prevent light penetration. Terrarium lamps ReptiGlo 2.0 (Exoterra, Montreal, Canada) were used as a light source (26 Watt, 1600 Lumen) (one for each microplate). To achieve different spectral ranges Tair MTO photographic filters $(72 \mathrm{~mm}$ diameter) were used. The filters spectral ranges were determined by using UV-160A spectrophotometer (Shimadzu, Japan). Light intensity $\left(5 \mu \mathrm{mol} / \mathrm{m}^{2} \times \mathrm{s}\right)$ was measured with Optel FR-10 (Optel, Poland).

Determination of enzymatic activities. Laccase activity in the culture fluid was measured spectrophotometrically at $525 \mathrm{~nm}$ in a Shimadzu UV-Vis $160 \mathrm{~A}$ spectrophotometer (Tokyo, Japan) using syringaldazine (4-hydroxy, 3,5-dimetoxybenzaldehyde) as a substrate (Leonowicz \& Grzywnowicz, 1981). The reaction mixture (1 $\mathrm{ml}$ ) contained $100 \mu \mathrm{l}$ of diluted enzyme, $500 \mu \mathrm{l}$ of $0.1 \mathrm{M}$ McIlvaine buffer, pH 5.5, $450 \mu \mathrm{l} \mathrm{H}_{2} \mathrm{O}$, the reaction was started by addition of $50 \mu \mathrm{l}$ of $0.5 \mathrm{mM}$ syryngaldazine in ethanol. One nano katal (nkat) of laccase activity was defined as the amount of enzyme catalysing the production of one nano mol of the coloured product (quinone, $\varepsilon^{\mathrm{M}}=65000 \mathrm{M}^{-1} \mathrm{~cm}^{-1}$ ) per second at $25^{\circ} \mathrm{C}$ and $\mathrm{pH} 5.5$, and expressed as nano katals per litre of culture (nkat/1).

Cellobiose dehydrogenase activity was measured by following the decrease in absorbance of the electron acceptor 2,6-dichloroindophenol (DCIP) (Sigma Chemical Co., St. Louis, MO, USA) at $520 \mathrm{~nm}\left(\varepsilon_{520}=6.8 \mathrm{mM}^{-1}\right.$ $\mathrm{cm}^{-1}$ ), $\mathrm{pH} 4.5$ and $30^{\circ} \mathrm{C}$ (Baminger et al., 2001; Karapetyan et al., 2006) with a Shimadzu UV-160A (Shimadzu, Tokyo, Japan) spectrophotometer. This assay measures the activity of an intact enzyme as well as of the catalytically active flavin domain. The reaction mixture (1 $\mathrm{ml}$ ) contained $50 \mu \mathrm{l}$ of $3 \mathrm{mM}$ DCIP (solution in water containing $10 \%$, v/v ethanol), $100 \mu$ lactose $(300 \mathrm{mM}$ in $100 \mathrm{mM}$ sodium acetate buffer, $\mathrm{pH} 4.5), 50 \mu \mathrm{l} \mathrm{NaF}$ $(80 \mathrm{mM} \mathrm{NaF})$ in water, and an appropriate amount of the same buffer. After temperature adjustment, the reaction was initiated by addition of a diluted $\mathrm{CDH}$ sample $(100 \mu \mathrm{l})$ and the decrease in absorbance was monitored during the first $60 \mathrm{~s}$. The final enzyme activity was expressed as nkat per liter. This assay was used for determination of the activity of the native enzyme as well as for the catalytically active flavin domain.

For the zymographic analysis of proteolytic activities, the samples of the culture medium were centrifuged $(10$ $\min$ at $4^{\circ} \mathrm{C}$ at $\left.10000 \times g\right)$, concentrated, and separated using Microcon Centrifugal Filter Units, 3000 NMWL (Millipore). Samples were applied to $10 \%$ separating gel containing $0.3 \%$ gelatin and $4 \%$ stacking gel (Laemmli, 1970). A mixture of samples and loading buffer were deposited into each line $(6 \mu \mathrm{l}, 5 \mu \mathrm{g}$ of protein). Protein concentration was determined according to Bradford (1976). The gels were run at alkaline $\mathrm{pH}$ under non-denaturating conditions in $4^{\circ} \mathrm{C}$ at $145 \mathrm{~V}$. After electrophoretic separation, the gels were incubated for $18 \mathrm{~h}$ at $37^{\circ} \mathrm{C}$ in $0.1 \mathrm{M}$ citrate-phosphate $(\mathrm{pH} 3.5)$ buffer. Next, the gels were stained with a dye Coomassie Brilliant Blue (R-250). Protease activity was visualized as white bands.

All presented results are expressed as the mean \pm S.D. from three independent experiments $(n=3)$. The mean values as well as standard deviation were calculated by the Excel program (Microsoft Office 2010 package) and only values of $p \leq 0.05$ were considered as statistically significant.

\section{RESULTS}

\section{Effect of different light wavelengths on laccase activities}

Laccase production was evaluated in Lindeberg \& Holm (1952) medium which was already successfully used to optimize this multicopper oxidase synthesis in Cerrena unicolor and Rbizoctonia praticola cultures (Janusz et al., 2006; Janusz et al., 2007). Quadruplicate cultures were used for each treatment at each wavelength evaluated (dark, white light, blue, red, and green). All three analysed fungal species reacted positively to light induction, however, to a varied extent. Blue light efficiently boosted laccase synthesis by Cerrena unicolor (Fig. 1) and Pycnoporus sanguineus (Fig. 2), whereas the highest activities (20654 nkat/l) of P. lindtneri laccase were observed when this fungus was maintained in the green light (Fig. 3). It should be mentioned that blue light seems to be the only wavelength inducing laccase production in $P$. sanguineus cultures. Even if laccase activities differed slightly among the light variants in Cerrena unicolor, green light enhances laccase production in $P$. lindnteri over four times comparing to dark experiment.

\section{Influence of light on cellobiose dehydrogenase activities}

Production of $\mathrm{CDH}$ was analysed in cellulose-based medium, which was already used for production of cellobiose dehydrogenase by Pycnoporus sanguineus (Sulej et al., 2013a) and Pblebia lindnteri (Sulej et al., 2013b). It may be clearly observed that cellobiose dehydrogenase produced by the analysed fungal strains was induced by different light wavelengths. The highest activities of $\mathrm{CDH}$ in cul- 

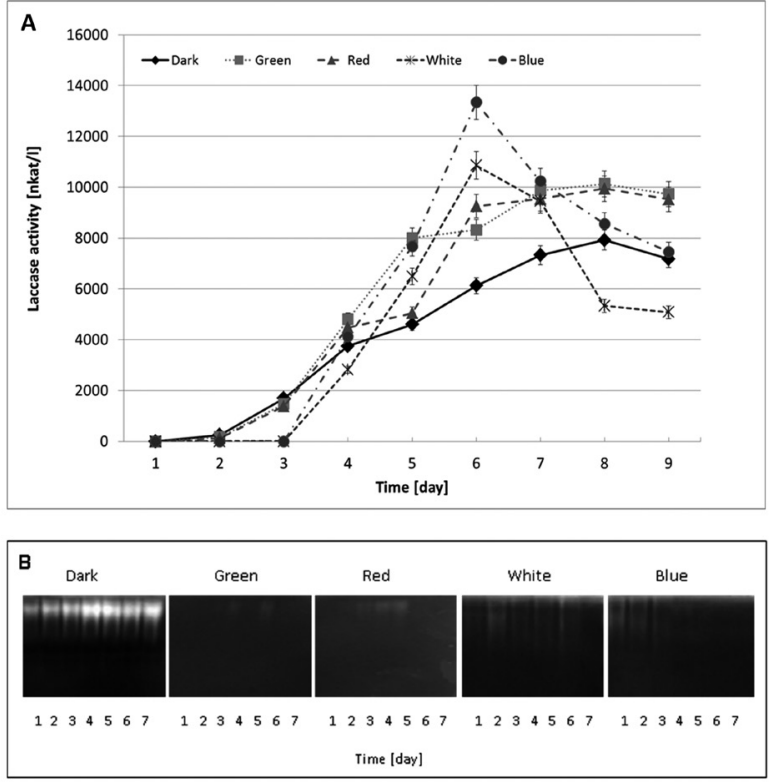

Figure 1. C. unicolor grown in Lindeberg and Holm medium under white, green, blue, red lights and in the dark.

(A) laccase activity. Proteolytic activities (B) were analyzed by gelatin zymography of the extracellular media. $6 \mu \mathrm{l}$ of samples $(5 \mu \mathrm{g}$ of protein) were loaded on a polyacrylamide gel containing $0.3 \%$ of gelatin. After electrophoresis, proteins were renaturated in the gel and the proteolytic activity was revealed after a 16-h incubation required for gelatin degradation

tures of C. unicolor (Fig. 4) and P. lindtneri (Fig. 5) where observed when green light was applied. Whereas $P$. sanguineus (Fig. 6) only under white light induction was able
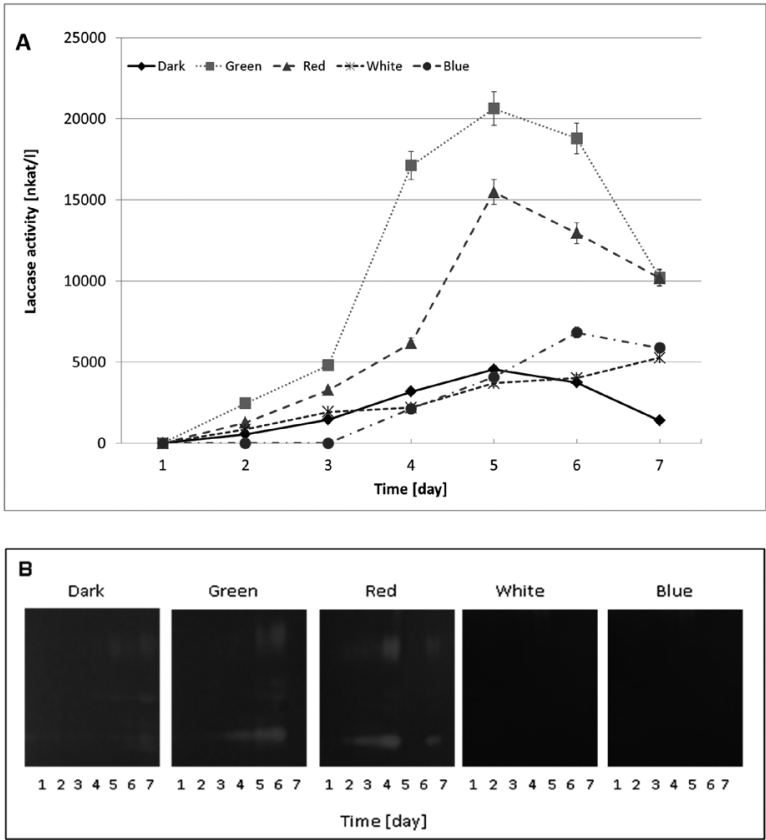

Figure 3. $P$. lindtneri grown in Lindeberg and Holm medium under white, green, blue, red lights and in the dark.

(A) laccase activity. Proteolytic activities (B) were analyzed by gelatin zymography of the extracellular media. $6 \mu \mathrm{l}$ of samples $(5 \mu \mathrm{g}$ of protein) were loaded on a polyacrylamide gel containing $0.3 \%$ of gelatin. After electrophoresis, proteins were renaturated in the gel and the proteolytic activity was revealed after a 16-h incubation required for gelatin degradation
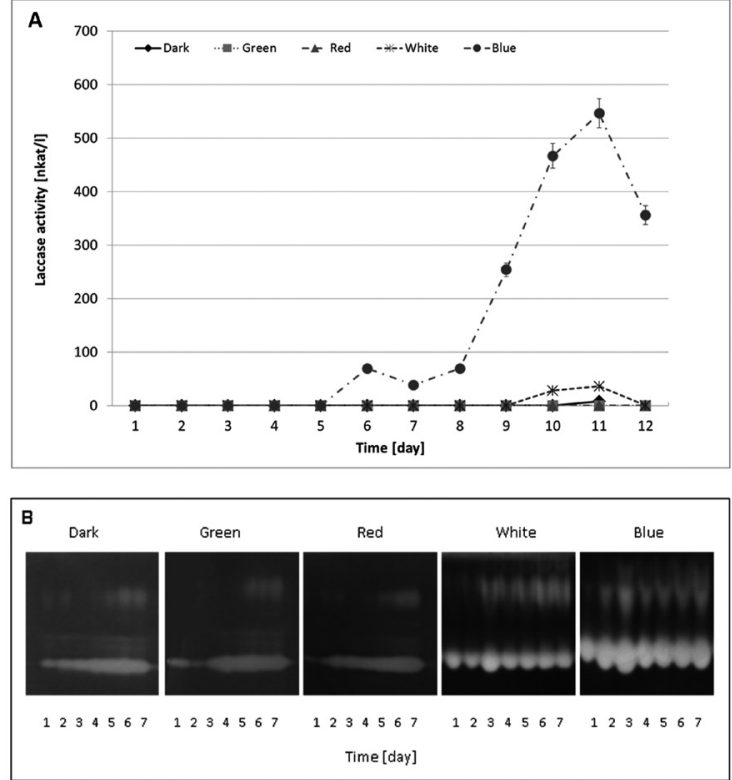

Figure 2. P. sanguineus grown in Lindeberg and Holm medium under white, green, blue, red lights and in the dark.

(A) laccase activity. Proteolytic activities (B) were analyzed by gelatin zymography of the extracellular media. $6 \mu \mathrm{l}$ of samples $(5 \mu \mathrm{g}$ of protein) were loaded on a polyacrylamide gel containing $0.3 \%$ of gelatin. After electrophoresis, proteins were renaturated in the gel and the proteolytic activity was revealed after a 16-h incubation required for gelatin degradation

to synthesize this enzyme efficiently. It is worth noting that green light stimulated $\mathrm{CDH}$ synthesis with an al-
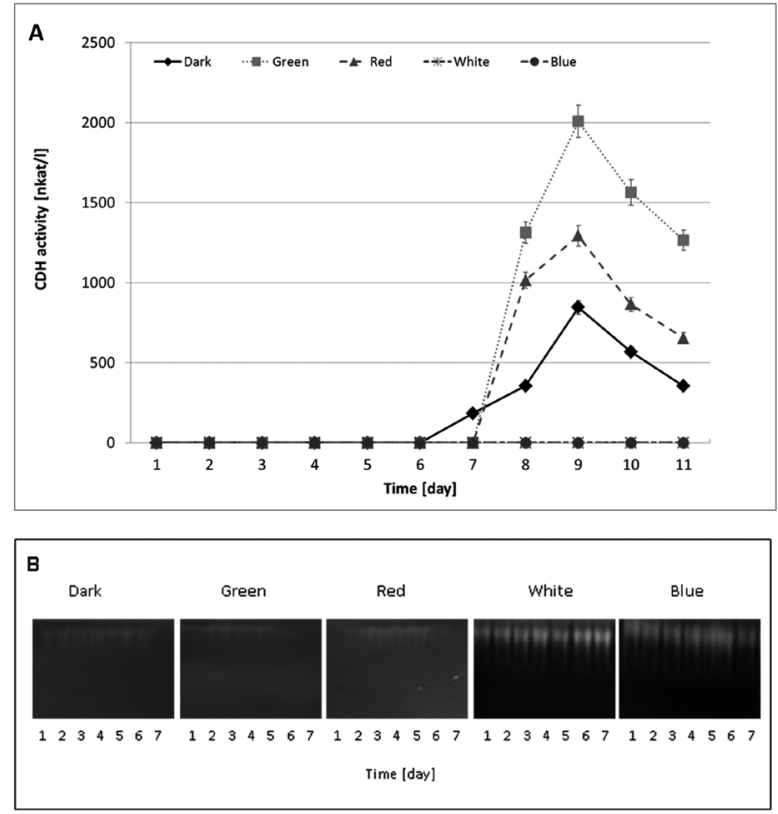

Figure 4. C. unicolor grown in cellulose-based medium under white, green, blue, red lights and in the dark.

(A) CDH activity. Proteolytic activities (B) were analyzed by gelatin zymography of the extracellular media. $6 \mu \mathrm{l}$ of samples $(5 \mu \mathrm{g}$ of protein) were loaded on a polyacrylamide gel containing $0.3 \%$ of gelatin. After electrophoresis, proteins were renaturated in the gel and the proteolytic activity was revealed after a 16-h incubation required for gelatin degradation 

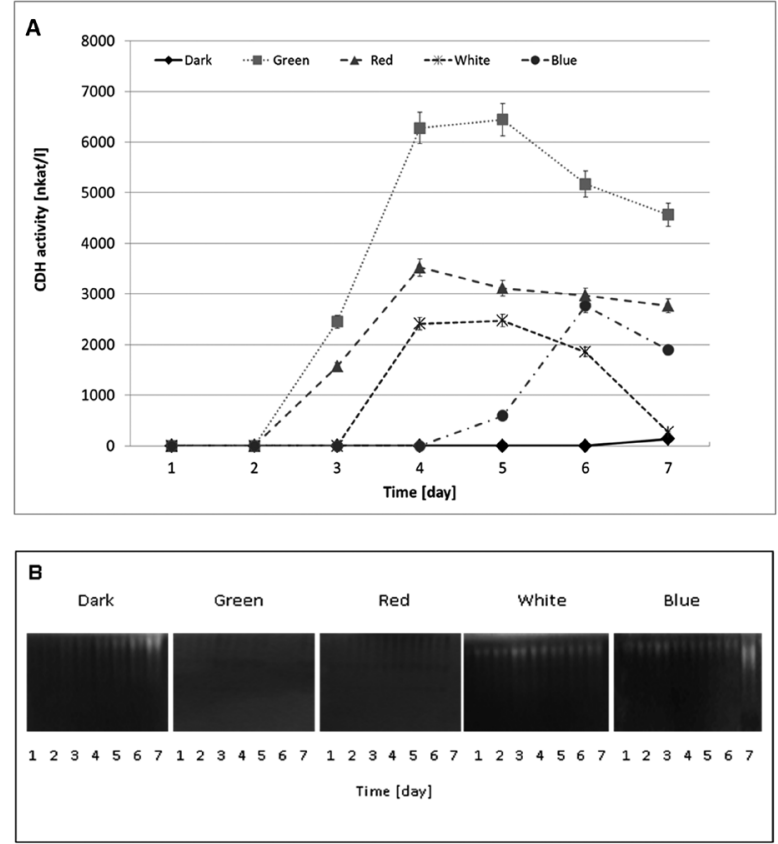

Figure 5. P. lindtneri grown in cellulose-based medium under white, green, blue, red lights and in the dark.

(A) CDH activity. Proteolytic activities (B) were analyzed by gelatin zymography of the extracellular media. $6 \mu$ of samples $(5 \mu \mathrm{g}$ of protein) were loaded on a polyacrylamide gel containing $0.3 \%$ of gelatin. After electrophoresis, proteins were renaturated in the gel and the proteolytic activity was revealed after a 16-h incubation required for gelatin degradation

most two-fold (C. unicolor) and over six-fold ( $P$. lindtneri) higher efficiency comparing to dark experiments.

\section{Protease activities dependence on light}

In order to analyse a possible influence of proteases on laccase and $\mathrm{CDH}$ activities, their synthesis was compared in both medium variants mentioned above under all the light wavelengths. It is clearly visible that the differences are noticeable not only between the light variants but also among the media used. Moreover, analysis of protease activities is complicated by the number of groups that are synthesized by these fungal strains. Phlebia lindtneri tend to produce a few proteases and those with low migration are rather observed in cellulose based medium (Fig. 5) or in Lindeberg and Holm medium (Fig. 3) induced by dark, light, or blue conditions. The electrophoretic analysis of C. unicolor proteases proved that this strain was able to secrete only a slow migrating fraction whose high activities may be observed mainly in the dark (Lindeberg and Holm medium - Fig. 1) or blue and white light (cellulose medium - Fig. 4). The most complicated picture is presented in the case of $P$. sanguineus, which produced even up to five protease fractions. The main difference is once again the slow migrating fraction of proteases, which is almost absent in Lindeberg and Holm medium (Fig. 2) in all lighting conditions except darkness and the last days of culture in white light. It should be pointed out that the same fractions tend to disappear in cellulose medium induced by green (day 3 of culture) or red light (4 day of culture) (Fig. 6). Moreover, the intensity of bands differs among mediums and it seems that the cellulose-based medium is better to obtain higher activities of slower migrating proteases than Lindeberg and Holm medium, which proved to be inducing faster migrating ones.
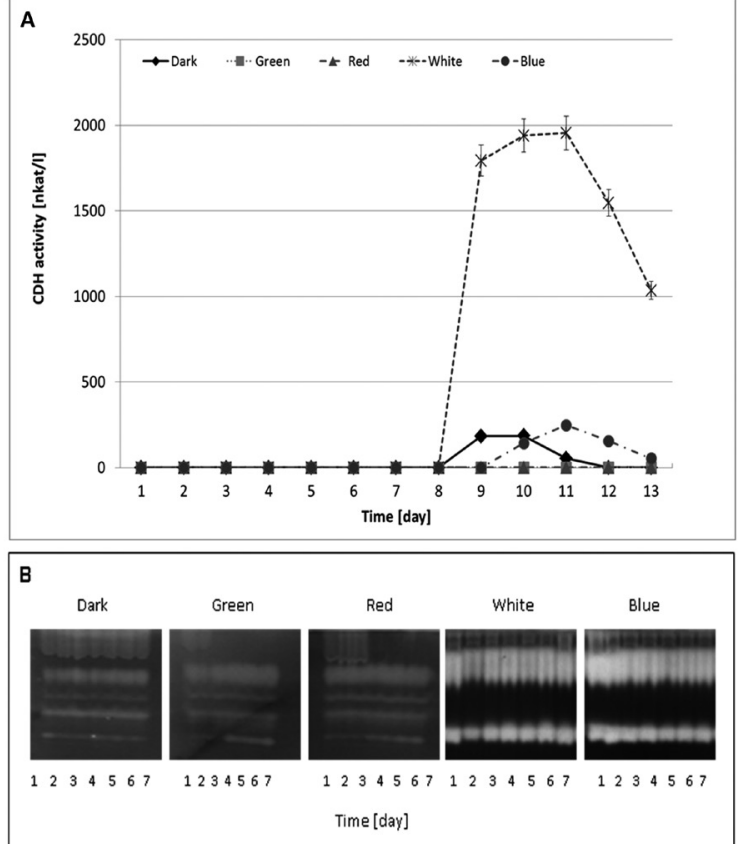

Figure 6. $P$. sanguineus grown in cellulose-based medium under white, green, blue, red lights and in the dark.

(A) CDH activity. Proteolytic activities (B) were analyzed by gelatin zymography of the extracellular media. $6 \mu \mathrm{l}$ of samples $(5 \mu \mathrm{g}$ of protein) were loaded on a polyacrylamide gel containing $0.3 \%$ of gelatin. After electrophoresis, proteins were renaturated in the gel and the proteolytic activity was revealed after a $16-\mathrm{h}$ incubation required for gelatin degradation.

\section{DISCUSSION}

Lighting conditions exert an impact on life on earth comparably to water or oxygen. For many years it was believed that fungal organism are poorly influenced by lightning conditions in comparison to plants. Thus, it may be surprising to what extent fungal metabolism and development is based not only on presence or absence of light but also on its length (Tisch \& Schmoll, 2010). Recently the explosion of papers considering light influence on Ascomycetes metabolism is observed. Until now, most papers analysing this subject are focussed on species belonging to the phyllum Ascomycetes. At the same time, the phyllum Basidiomycetes, which is equally advanced metabolically, is hardly examined in terms of the influence of light. However, in recent years, molecular techniques have been increasingly used to localize homologues of photosensory proteins in some basidiomycetous genomes (Idnurm et al., 2010). Among them, a number of species engaged in wood decomposition (Phanerochate chrysosporium or Lentinulla edodes) may be found as parasites or saprophytes living mainly in forests habitats. In the available genomes of Phlebia brevispora and Cerrena unicolor, photoreceptor proteins: phytochromes or PAS (http:// genome.jgi-psf.org/) may be found. It is well known that life in forests depends not only on light, due to the sunlight angle, changing seasons or time of the day, but also on shadows cast by taller organisms. Therefore, it seems natural that life of wood decomposing fungi may be to some extent influenced by lighting conditions. Moreover, many papers have proved the influence of light on metabolism of moulds comprising a number of enzymes engaged in amino acid or carbohydrate metabolism (including cellulases) (Bayram et al., 2008; Fox \& Howlett, 2008; Tisch \& Schmoll, 2010). As indicated by the re- 
sults presented above, wood parasites/saprophytes face the problem of degradation of the complex biopolymer - lignocellulose, which is successfully undertaken by engaging a number of enzymes decomposing carbohydrates or proteins. It seems obvious that their synthesis may be somehow regulated by light; therefore, we have examined the ability of three species to produce proteases, cellobiose dehydrogenase (an enzyme that together with lytic polysaccharide monooxygenase starts cellulose degradation) and, finally, laccase - the best described lignin-degrading enzyme. Moreover, the activity of extracellular proteases may also regulate the levels of $\mathrm{CDH}$ and laccase, which cooperate and to some extent are dependent on each other in lignocellulose decomposition (Henriksson et al., 2000). Until now, only Ramirez et al. (2010) have found green light to boost lignin peroxidase production in Phanerochaete chrysosporium. Similarly, our results showed that green light stimulated P. lindtneri laccase and $\mathrm{CDH}$ produced by $P$. lindtneri and $C$. unicolor. It should be mentioned that any induction of the synthesis of both enzymes may be altered by simultaneous regulation by presence/absence of medium components (carbon or nitrogen source). Similar results were obtained by Schmoll et al. (2005), who proved that light must be an additional external factor influencing cellulase expression in Hypocrea jecorina beside the enzyme synthesis inducer (cellulose). Therefore, production of the cellulose degrading enzyme - cellobiose dehydrogenase by the species used should be analysed in terms of the presence of cellulose in culture medium. In recent years, light was proved to regulate the levels of cAMP in N. crassa via WWC (white collar complex); at the same time, cAMP is responsible for regulation of expression of a number of enzymes engaged in lignocellulose degradation (Chen et al., 2009b; Smith et al., 2010; Schmoll et al., 2012; Janusz et al., 2013). Moreover, blue light is responsible for increased levels of cAMP-dependent kinase in cultures of Trichoderma atroviride (Casas-Flores et al., 2006). It should be mentioned that CRE sites were found in promoter regions of enzymes engaged in wood degradation. They are responsible for reaction to carbon repression through cAMP and moreover it was already proved that WCC in $N$. crassa acts on cre1 which also regulates expression of cellulases and hemicellulases (Chen et al., 2009b; Janusz et al., 2013). It seems light may regulate enzyme expression by controlling cAMP levels and through carbon catabolite repressor protein. WCC in fungi is responsible for reaction to blue light exposure; therefore, it helps understand the enhanced laccase activities in cultures of $C$. unicolor and $P$. sanguineus illuminated by blue wavelength. Moreover, laccase is considered as a stress-response enzyme in fungi and 39 out of 178 light-regulated genes in Trichoderma are related to the response to stress factors (Schmoll et al., 2010; Yang et al., 2012). Both laccase and cellobiose dehydrogenase as extracellular proteins may undergo maturation and therefore their activity is dependent on the presence/absence of proteases (Habu et al., 1993; Palmieri et al., 2000; Staszczak et al., 2000). Considering the results obtained by Mayer (2006), who described changes in transport and protease dependent maturation of tomato polyphenol oxidase influenced by light, we examined changes in proteases activities in both described mediums. The results obtained showed changes in not only laccase or cellobiose dehydrogenase activities but also protease activities, which are correlated to each other to some extent. The differences in light wavelengths that induce certain enzymes may be dependent on the kind of photosensory proteins expressed in the fungal organism. Analysis of fungal genomes indi- cated not only quantitative differences but also changes in the gene copy number from one up to five. Apparently, as a result of the differences in the complexity of fungal response to light, still unknown photosensory proteins are suspected to exist (Idnurm et al., 2010). In the light of the presented results, there are opportunities to use light to obtain high activities of biotechnologically interesting enzymes without the need to use chemical inducers, particularly in the case of laccase. Beside the biotechnological value of the presented results, the studies on the dependence of wood decay fungi on light should be analysed in detail in future, because it seems that light may be more crucial in the life of white rot fungi than it was suspected.

\section{Acknowledgements}

This work was financially supported by the National Science Centre (Poland) based on the decision number DEC-2013/09/B/NZ9/01829.

\section{REFERENCES}

Baminger U, Subramaniam SS, Renganathan V, Haltrich D (2001) Purification and characterization of cellobiose dehydrogenase from the plant pathogen Sclerotium (Athelia) rolfsii. Appl Environ Microbiol 67: 1766-1774. Doi 10.1128/Aem.67.4.1766-1774.2001.

Bayram O, Krappmann S, Ni M, Bok JW, Helmstaedt K, Valerius O, Braus-Stromeyer S, Kwon NJ, Keller NP, Yu JH, Braus GH (2008) $\mathrm{VelB} / \mathrm{VeA} / \mathrm{LaeA}$ complex coordinates light signal with fungal development and secondary metabolism. Science 320: 1504-1506. DOI: 10.1126/science.1155888.

Bradford MM (1976) A rapid and sensitive method for the quantitation of microgram quantities of protein utilizing the principle of proteindye binding. Anal Biochem 72: 248-254

Casas-Flores S, Rios-Momberg M, Rosales-Saavedra T, MartinezHernandez P, Olmedo-Monfil V, Herrera-Estrella A (2006) Cross talk between a fungal blue-light perception system and the cyclic AMP signaling pathway. Eukaryot Cell 5: 499-506. Doi 10.1128/ Ec.5.3.499-506.2006.

Chen CH, Ringelberg CS, Gross RH, Dunlap JC, Loros JJ (2009a) Genome-wide analysis of light-inducible responses reveals hierarchical light signalling in Neurospora. EMBO J 28: 1029-1042. Doi 10.1038/ emboj.2009.54.

Chen CH, Ringelberg CS, Gross RH, Dunlap JC, Loros JJ (2009b) Genome-wide analysis of light-inducible responses reveals hierarchical light signalling in Neurospora. Embo J 28: 1029-1042. DOI 10.1038/ emboj.2009.54.

Dong W, Tang X, Yu Y, Nilsen R, Kim R, Griffith J, Arnold J, Schuttler HB (2008) Systems biology of the clock in Neurospora crassa. PLoS One 3: e3105. Doi 10.1371/journal.pone.0003105.

Fang J, Huang F, Gao P (1999) Optimization of cellobiose dehydrogenase production by Schirophyllum commune and effect of the enzyme on kraft pulp bleaching by ligninases. Process Biochem 34: 957-961. Doi 10.1016/S0032-9592(99)00016-3.

Fox EM, Howlett BJ (2008) Secondary metabolism: regulation and role in fungal biology. Curr Opin Microbiol 11: 481-487. Doi 10.1016/j. mib.2008.10.007.

Habu N, Samejima M, Dean JF, Eriksson KE (1993) Release of the FAD domain from cellobiose oxidase by proteases from cellulolytic cultures of Phanerochaete chrysosporium. FEBS Lett 327: 161-164.

Henriksson G, Johansson G, Pettersson G (2000) A critical review of cellobiose dehydrogenases. J Biotechnol 78: 93-113.

Idnurm A, Heitman J (2010) Ferrochelatase is a conserved downstream target of the blue light-sensing White collar complex in fungi. Microbiol-Sgm 156: 2393-2407.

Idnurm A, Verma S, Corrochano LM (2010) A glimpse into the basis of vision in the kingdom Mycota. Fungal Genet Biol 47: 881-892. DOI 10.1016/j.fgb.2010.04.009.

Janusz G, Kucharzyk KH, Pawlik A, Staszczak M, Paszczynski AJ (2013) Fungal laccase, manganese peroxidase and lignin peroxidase: gene expression and regulation. Ensyme Microb Technol 52: 1-12. DOI 10.1016/j.enzmictec.2012.10.003

Janusz G, Rogalski J, Barwinska M, Szczodrak J (2006) Effects of culture conditions on production of extracellular laccase by Rhizoctonia praticola. Pol J Microbiol 55: 309-319.

Janusz G, Rogalski J, Szczodrak J (2007) Increased production of laccase by Cerrena unicolor in submerged liquid cultures. World J Microbiol Biotechnol 23: 1459-1464. DOI 10.1007/s11274-007-9390-y. 
Karapetyan KN, Fedorova TV, Vasil'chenko LG, Ludwig R, Haltrich D, Rabinovich ML (2006) Properties of neutral cellobiose dehydrogenase from the ascomycete Chaetomium sp. INBI 2-26(-) and comparison with basidiomycetous cellobiose dehydrogenases. J Biotechnol 121: 34 -48. DOI 10.1016/j.jbiotec.2005.06.024

Kirk TK (1987) Lignin-Degrading Enzymes. Philos T Roy Soc A 321: $461-474$.

Laemmli UK (1970) Cleavage of structural proteins during the assembly of the head of bacteriophage T4. Nature 227: 680-685.

Leonowicz A, Grzywnowicz K (1981) Quantitative estimation of laccase forms in some white-rot fungi using syringaldazine as a substrate. Enzyme Microb Technol 3: 55-58. Doi 10.1016/01410229(81)90036-3.

Lindeberg G, Holm G (1952) Occurrence of tyrosinase and laccase in fruit bodies and mycelia of some Hymenomycetes. Physiol Plant 5: $100-114$.

Mayer AM (2006) Polyphenol oxidases in plants and fungi: going places? A review. Phytochemistry 67: 2318-2331. DOI 10.1016/j.phytochem.2006.08.006.

Palmieri G, Giardina P, Bianco C, Fontanella B, Sannia G (2000) Copper induction of laccase isoenzymes in the ligninolytic fungus Pleurotus ostreatus. Appl Environ Microbiol 66: 920-924.

Purschwitz J, Muller S, Kastner C, Fischer R (2006) Seeing the rainbow: light sensing in fungi. Curr Opin Microbiol 9: 566-571. DOI 10.1016/j.mib.2006.10.011.

Ramirez DA, Munoz SV, Atehortua L, Michel FC, Jr. (2010) Effects of different wavelengths of light on lignin peroxidase production by the white-rot fungi Phanerochaete chrysosporium grown in submerged cultures. Bioresour Technol 101: 9213-9220. DOI 10.1016/j. biortech.2010.06.114.

Rosales-Saavedra T, Esquivel-Naranjo EU, Casas-Flores S, MartinezHernandez P, Ibarra-Laclette E, Cortes-Penagos C, Herrera-Estrella A (2006) Novel light-regulated genes in Trichoderma atroviride: a dissection by cDNA microarrays. Microbiology 152: 3305-3317. DOI 10.1099/mic.0.29000-0.

Schmoll M, Esquivel-Naranjo EU, Herrera-Estrella A (2010) Trichoderma in the light of day - Physiology and development. Fungal Genet Biol 47: 909-916. DOI 10.1016/j.fgb.2010.04.010.
Schmoll M, Franchi L, Kubicek CP (2005) Envoy, a PAS/LOV domain protein of Hypocrea jecorina (Anamorph Trichoderma reesei), modulates cellulase gene transcription in response to light. Eukaryot Cell 4: 1998-2007. DOI 10.1128/EC.4.12.1998-2007.2005.

Schmoll M, Tian CG, Sun JP, Tisch D, Glass NL (2012) Unravelling the molecular basis for light modulated cellulase gene expression the role of photoreceptors in Neurospora crassa. BMC Genomics 13. Doi 10.1186/1471-2164-13-127.

Smith JE, Berry DR (1974). An introduction to biochemistry of fungal development. London; New York: Academic Press.

Smith KM, Sancar G, Dekhang R, Sullivan CM, Li SJ, Tag AG, Sancar C, Bredeweg EL, Priest HD, McCormick RF, Thomas TL, Carrington JC, Stajich JE, Bell-Pedersen D, Brunner M, Freitag M (2010) Transcription factors in light and circadian clock signaling networks revealed by genomewide mapping of direct targets for neurospora white collar complex. Eukaryot Cell 9: 1549-1556. Doi 10.1128/Ec.00154-10.

Staszczak M, Zdunek E, Leonowicz A (2000) Studies on the role of proteases in the white-rot fungus Trametes versicolor: effect of PMSF and chloroquine on ligninolytic enzymes activity. J Basic Microbiol 40: 51-63.

Sulej J, Janusz G, Mazur A, Zuber K, Zebracka A, Rogalski J (2013a) Cellobiose dehydrogenase from the ligninolytic basidiomycete Phlebia lindtneri. Process Biochem 48: 1715-1723. DOI 10.1016/j. procbio.2013.08.003.

Sulej J, Janusz G, Osinska-Jaroszuk M, Malek P, Mazur A, Komaniecka I, Choma A, Rogalski J (2013b) Characterization of cellobiose dehydrogenase and its FAD-domain from the ligninolytic basidiomycete Pycnoporus sanguineus. Ensyme Microb Technol 53: 427-437. DOI 10.1016/j.enzmictec.2013.09.007.

Tisch D, Schmoll M (2010) Light regulation of metabolic pathways in fungi. Appl Microbiol Biotechnol 85: 1259-1277. DOI 10.1007/s00253009-2320-1.

Yang Y, Fan FF, Zhuo R, Ma FY, Gong YM, Wan X, Jiang ML, Zhang XY (2012) Expression of the laccase gene from a white rot fungus in Pichia pastoris can enhance the resistance of this yeast to $\mathrm{H}_{2} \mathrm{O}_{2}$-mediated oxidative stress by stimulating the glutathione-based antioxidative system. Appl Environ Microbiol 78: 5845-5854. Doi 10.1128/Aem.00218-12. 